\title{
Fibroblastik/myofibroblastik benign ve lokal agresif neoplaziler ve nörofibromalarda DOG1 ekspresyon profili
}

\author{
DOG1 expression profile of benign and locally aggressive \\ fibroblastic/myofibroblastic neoplasms and neurofibromas
}

\section{Cevriye Cansız Ersöz*, Duygu Kankaya, Saba Kiremitçi, Gülşah Kaygusuz}

Tıbbi Patoloji Anabilim Dalı (Dr. C. C. Ersöz, Yrd. Doç. Dr. D. Kankaya, Yrd. Doç. Dr. S. Kiremitçi, Doç. Dr. G. Kaygusuz), Ankara Üniversitesi Tıp Fakültesi, TR-06620 Ankara

\begin{abstract}
Özet
Amaç. Gastrointestinal stromal tümörlerde (GİST) spesifik olarak ekspresyon gösteren ve kalsiyum bağımlı klorid kanalı olarak bilinen DOG1, gastrointestinal stromal tümörlerin diğer sarkomlardan ayrımında kullanılan tanısal bir belirteçtir. Çeşitli araştırmalarda Gastrointestinal stromal tümor dışı mezenşimal tümörlerde değişen oranda DOG1 ekspresyonu bildirilmiştir. Bu çalışmada Nodüler fasiit, Nörofibroma, Desmoid tümör ve Dermatofibrosarkoma Protuberans olgularından oluşan bir vaka serisinde DOG1 ekspresyonu araştırılmıştır. Yöntem. Bu çalışmaya, Ankara Üniversitesi Tıp Fakültesi Tibbi Patoloji Anabilim Dalı'nda 2005-2012 yılları arasında tanı almış Nodüler Fasiit ( $\mathrm{n}=8)$, Desmoid tümör $(\mathrm{n}=8)$, Dermatofibrosarkoma Protuberans $(\mathrm{n}=8)$ ve Nörofibroma $(\mathrm{n}=8)$ vakaları dahil edilmiştir. Parafin bloklardan elde edilen kesitlerde otomatik immün boyama cihazı ile DOG1 çalışılmıştır. Bulgular. Yalnızca bir Nodüler fasiit olgusunda (1/8) fokal soluk sitoplazmik boyanma izlenirken, diğer olgularda DOG1 ekspresyonu saptanmamıştır. Sonuç. Fibroblastik /myofibroblastik benign ve lokal agresif neoplaziler ve nörofibromalarda DOG1'in tanısal değeri yoktur.
\end{abstract}

Anahtar sözcükler: DOG1, nörofibroma, nodüler fasiit, desmoid tümör, dermatofibrosarkoma protuberans

\begin{abstract}
Aim. DOG1 is a calcium-dependent chlorid channel, that shows specific expression in Gastrointestinal stromal tumors (GIST) can be used in differential diagnosis of these tumors with other soft tissue sarcomas. In several studies, DOG1 expression has been reported in varying proportions in Non-GIST mesenchymal tumors. In this study, we aimed to find the DOG1 expression profile in Nodular fasciit, Neurofibroma, Desmoid tumors and Dermatofibrosarcoma protuberans. Method. Nodular fasciit $(n=8)$, Neurofibroma $(n=8)$, Desmoid tumors $(n=8)$ and Dermatofibrosarcoma protuberans $(n=8)$ cases, diagnosed in Ankara University, Faculty of Medicine, Department of Pathology between 2005-2012, were included in this study. Results. Focal and pale DOG1 reactivity was seen only in one case of Nodular fasciit (1/8) whereas the remainig cases were negative with DOG1. Conclusion. DOG1 has no diagnostic value in benign and locally aggressive fibroblastic/myofibroblastic neoplasms and neurofibromas.
\end{abstract}

Keywords: DOG1, neurofibroma, nodular fasciitis, desmoid tumor, dermatofibrosarcoma protuberans

Geliş tarihi/Received: 08 Şubat 2014; Kabul tarihi/Accepted: 13 Mayıs 2014

\section{*iletişim adresi:}

Dr. Cevriye Cansız Ersöz, Tıbbi Patoloji Anabilim Dalı, Ankara Üniversitesi Tıp Fakültesi, TR06620 Ankara. E-posta: cevriye80@yahoo.com 


\section{Giriş}

Gastrointestinal stromal tümörler (GİST) gastrointestinal sistemin en sık karş1laş1lan mezenşimal tümörleridir. En sık mide ve ince barsakta izlenirler. Özofagus, kolon ve rektum dışında; omentum, mezenter, retroperiton gibi ekstragastrointestinal lokalizasyonlarda da izlenebilirler; \%70 oranda iğsi morfolojide izlenirken, epiteloid (\%20) ve mikst fenotipte (\%10) görülebilmektedir [1]. Bu tümörler otonom sinir uyarıs1 oluşturan "pace maker" intersitisyel Cajal hücresi kökenlidir. Bu tümörün patogenezinde, tirozin kinaz ilişkili reseptörler olan KIT (\%80) ve PDGFRA'ın (\%10) otonom uyarılması sonucunu doğuran mutasyonların bulunduğu bilinmektedir [2]. Bu transmembran tirozin kinaz reseptörlerindeki mutasyonlar sonucu hücre diferansiasyonu, proliferasyonu ve apopitozda etkili yolakların aktivasyonu ile tümör hücre büyümesi gerçekleşir [3].

GIST olgularında saptanan transmembran proteini 1 (DOG1) transmembran Ca-bağımlı klorid kanalı olarak; böbrek, hava yolu, gastrointestinal kanal, pankreas ve tükrük bezi epitelinde elektrolit ve su transportundaki sekretuar fonksiyonu yanında nöronal hücreler ve myositlerin uyarılması, endotelyal ve düz kas tonusu gibi duyusal ve kontraktil fonksiyonlar gibi önemli fizyolojik durumlarda etkilidir [4]. GISST'lerde DOG1 ekspresyonu ilk olarak 2004 yılında West R. ve ark. [5] tarafından tanımlanmıştır. Daha sonra yapılan çalışmalarla GIST'lerde DOG1 ekspresyonunun \%95'in üzerinde olduğu ve bu pozitifliğin KIT ve PDGFRA mutasyon durumu, tümör lokalizasyonu, boyutu, histolojik derecesi ve hasta yaşından bağımsız olduğu saptanmıştır. GíST vakalarının çoğunda tanı klinik, histolojik ve immünohistokimyasal bulgular (özellikle KIT/CD117) ile konulabilmektedir. GIST'lerin yaklaşı $\% 5$ kadarında KIT ekspresyonu izlenmemekte, tanı için KIT ve PDGFRA mutasyon analizi yardımcı olabilmektedir. Ancak mutasyon analizi yöntemleri hem pahalı hem de zaman alıcı olabilmektedir [6]. Bu nedenle GIST tanısının doğru, hızlı ve güvenilir bir şekilde konabilmesi için DOG1 önemli bir belirteç haline gelmiştir. Liegl B. ve ark. [7]. KIT negatif olan \%36 vakada DOG1 pozitifliği ortaya koymuşlardır. $\mathrm{Bu}$ grup hastaların da tirozin kinaz inhibitörlerinden fayda gördügü düşünülürse DOG1'in GISSTleri saptamada önemli bir rolü olduğu düşünülebilir.

Biz bu çalışmada, GİST ayırıcı tanısında yer alabilen Nörofibroma, Desmoid tümör, Dermatofibrosarkoma protuberans ve ayrıca fasiaları, subkutanöz dokuyu tutabilen Nodüler Fasiit’te DOG1 ekspresyon profilini araştırmayı amaçladık.

\section{Gereç ve yöntem}

Bu çalışmaya Ankara Üniversitesi Tıp Fakültesi Tıbbi Patoloji Anabilim Dalı'nda 20052012 yılları arasında tanı almış Nodüler Fasiit $(n=8)$, Desmoid tümör $(n=8)$, Dermatofibrosarkoma Protuberans $(n=8)$ ve Nörofibroma $(n=8)$ vakaları dahil edilmiştir. $\mathrm{Bu}$ vakaların H.E. boyalı preparatları yeniden değerlendirilmiş, demonstratif alanları seçilmiş ve bu alanların parafin bloklarından elde edilen kesitlerde otomatik immün boyama cihazı ile DOG1 (CellMarque, Clone: SP31, 1/50) çalışılmıştır.

\section{Bulgular}

Yapılan immünohistokimyasal incelemelerde toplam 32 vakadan yalnızca bir Nodüler Fasiit olgusunda (1/8) fokal soluk sitoplazmik boyanma izlenirken, diğer tüm olgularda DOG1 ekspresyonu saptanmamıştır (Resim 1a, b). 

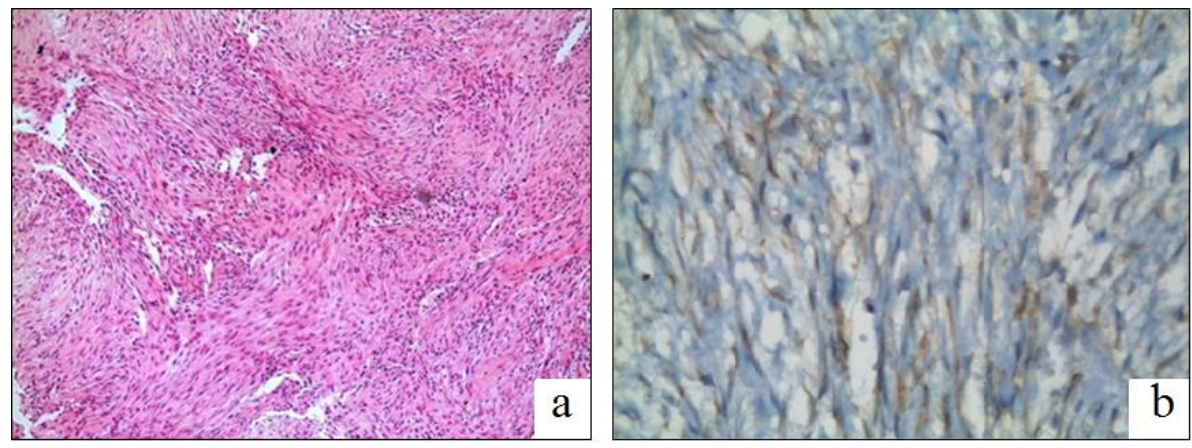

Resim 1. a; Nodüler Fasiit olgusunda lezyonel iğsi hücreler (hematoksilen\&eozinx100). b; bu hücrelerdeki DOG1 ekspresyonu (x400).

\section{Tartışma}

DOG1 geni insanda kromozom 11q13'ün CCND1-EMS1 loküsünde yer almaktadır. Meme, prostat, tükrük bezi, karaciğer, mide, testis, pankreas, safra kesesi, mesane, ter bezleri, akciğer, renal tübülüslerde ve endometrium gibi dokularda Cajal hücrelerinde, duyusal nöronlarda, retinada, leydig hücrelerinde, spermatositlerde immünhistokimyasal olarak DOG1 pozitifliği izlenebilmektedir. DOG1 ekspresyonu baş-boyun skuamöz hücreli karsinomaları, paratiroid ve meme tümörleri, pankreatik ve gastrik kanserler gibi birçok başka tümörde bildirilmiştir [4].

2004 yılında West R. ve ark. [5] yaptıkları çalışmada, 149’u GİST olmak üzere 587 yumuşak doku tümöründe DOG1 (rabbit poliklonal antikor-5284) ekspresyonunu araştırmışlardır. Bu çalışmada; DOG1 pozitifliği GíST'lerde \%97,8 olarak saptanmıştır. 438 GIST dışı yumuşak doku tümöründen yalnızca 4'ünde DOG1 pozitifliği saptanmıştır (Sinovyal sarkoma, Leiomyosarkoma, Fibrosarkoma ve Ewing sarkoma).

Lopes ve ark.'nın [6] yaptıkları çalışmada, GİST vakalarının \%96,1'inin DOG1 K9 klonu ile pozitif boyandığı tesbit edilmiştir. Aynı çalışmada Leiomyosarkomların \%1,6'sında $(\mathrm{n}=1 / 61)$, Sinovyal sarkomlarin \%8,8'inde $(\mathrm{n}=5 / 57)$ ve Anjiosarkomların \%7,1'inde $(\mathrm{n}=1 / 14)$ K9 klonu pozitif bulunmuştur. Bu çalışmada yer alan 11 Nodüler Fasiit olgusunda DOG1 ile boyanma izlenmemiştir. Bizim çalışmamızda SP31 klonu kullanılmış ancak 1 Nodüler Fasiit olgusu dışında DOG1 ile boyanma izlenmemiştir.

Hemminger ve ark.'nın [9] yaptığı çalışmada ise 117 GíST dışı yumuşak doku tümörü olgusunun yalnızca 3 tanesinde (Desmoplastik Melanoma, malign periferik sinir kılıfi tümörü ve Schwannoma olguları) DOG1 pozitifliği saptanmıştır. Sinovyal sarkom, düşük dereceli fibromiksoid sarkom, Leiomyosarkom, Perinöroma, Nörofibroma, Anjiosarkoma olgularında DOG1 negatif bulunmuştur [8]. Bir başka çalışmada, 23 farklı neoplazi grubunun temsil edildiği 125 vakalık seride yalnızca üç yumuşak doku tümörü vakasında (Ewing sarkomu, Glomus tümörü ve Sinovyal sarkom) DOG1 pozitifliği saptanmıştır. Bu tümörlerdeki DOG1 boyanmasının fokal ve zayıf olduğu belirtilmektedir.

2008 yılında Espinosa ve ark. [10] tarafından yapılan çalışmada, çalışmaya dahil edilen Nörofibroma, Desmoid tümör ve Dermatofibrosarkoma vakalarında bizim çalışmamızdakine benzer şekilde DOG1 negatif bulunmuştur.

Sonuç olarak farklı çalışmalarda GIST ayırıcı tanısında yer alan Sinovial sarkom, Leiomyosarkom, Fibrosarkom, Ewing sarkomu, malign periferik sinir kılıfı tümörü, Glomus tümörü, Peritoneal leiomyomatöz lezyonlar, Anjiosarkom, Schwannom ve Desmoplastik melanomlarda \%0,3-2,5 oranında fokal ve soluk DOG1 ekspresyonundan bahsedilmektedir [5, 6, 8-10]. Bizim çalışmamızda, daha önce yapılan çalışmalara benzer şekilde Nörofibroma, Desmoid tümör ve Dermatofibrosarkoma protuberans olgularında DOG1 ekspresyonu saptanmamış, DOG1'in bu tümörlerde tanısal değerinin olmadığ 1 anlaşılmıştır. 


\section{Kaynaklar}

1. Miettinen M. Gastrointestinal stromal tumors: Pathology and prognosis at different sites. Semin Diagn Pathol 2006; 23: 70-83.

2. Lasota J. KIT and PDGFRA mutations in gastrointestinal stromal tumors (GISTs). Semin Diagn Pathol 2006; 23: 91-102.

3. Joensuu H. Risk stratification of patients diagnosed with gastrointestinal stromal tumor. Hum Pathol 2008; 39: 1411-9.

4. Katoh M. FLJ10261 gene, located within the CCND1- EMS1 locus on human chromosome 11q13, encodes the eight-transmembrane protein homologous to C12orf3, C11orf25 and FLJ34272 gene products. Int. J. Oncol 2003; 22; 137581.

5. West RB. The novel marker, DOG1, is expressed ubiquitously in gastrointestinal stromal tumors irrespective of KIT or PDGFRA mutation status. Am. J of Pathol 2004; 165: 107-13.

6. Lopes LF. DOG1 for the diagnosis of gastrointestinal stromal tumor (GIST): Comparison between 2 different antibodies. Appl Immunohistochem Mol Morphol 2010; 18: 333-7.

7. Liegl B. Monoclonal antibody DOG1.1 shows higher sensitivity than KIT in the diagnosis of gastrointestinal stromal tumors including unusual subtypes. Am. J. Surg. Pathol 2009; 33; 437-46.

8. Hemminger J. Discovered on gastrointestinal stromal tumours 1 (DOG1) expression in non-gastrointestinal stromal tumour (GIST) neoplasms. Histopathology 2012; 61; 170-7.

9. Wong NA. Specificity of DOG1 (K9 clone) and protein kinase theta (clone 27) as immunohistochemical markers of gastrointestinal stromal tumor. Histopathology 2010; 57: 250-8.

10. Espinosa I. A novel monoclonal antibody against DOG1 is a sensitive and specific marker for gastrointestinal stromal tumors. Am J Surg Pathol 2008; 32: $210-8$. 